Portland State University

PDXScholar

2-23-1972

\title{
Degree of Depression in Women Preceding Abortion at the University of Oregon Medical School
}

William M. Nathe

Portland State University

Ike R. Lacefield

Portland State University

Follow this and additional works at: https://pdxscholar.library.pdx.edu/open_access_etds

Part of the Health Psychology Commons, and the Social Work Commons Let us know how access to this document benefits you.

\section{Recommended Citation}

Nathe, William M. and Lacefield, Ike R., "Degree of Depression in Women Preceding Abortion at the University of Oregon Medical School" (1972). Dissertations and Theses. Paper 2619.

https://doi.org/10.15760/etd.2615

This Thesis is brought to you for free and open access. It has been accepted for inclusion in Dissertations and Theses by an authorized administrator of PDXScholar. Please contact us if we can make this document more accessible: pdxscholar@pdx.edu. 
DEGREE OF DEPRESSION IN WOMEN PRECEDING AEORTION

AT THE

UNIVERSITY OF OREGON MEDICAL SCHOOL

WIILIAM M. NATHE

IKE R. LACEFIELD

A practicum submitted in partial fulfillment of the requirements for the degree of

MASTER OF SOCIAL WORK

Portland State University

1972 
TO THE OFFICE OF GRADUATE STUDIES:

The members of the Committee approve the practicum of W1IIIam M. Nathe and Ike R. Lacefleld presented February 23, 1972.

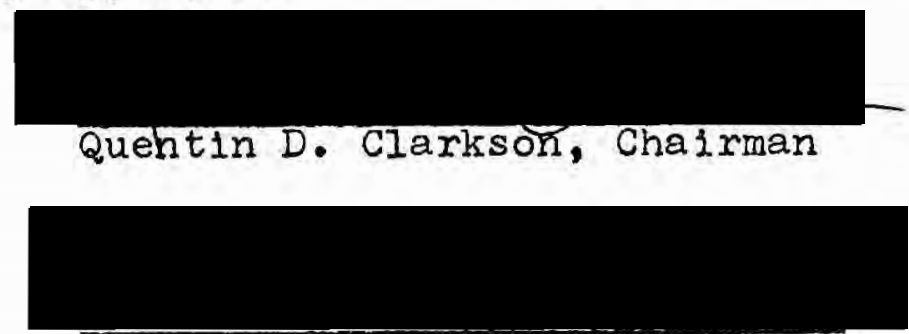

June Dunn

APPROVED:

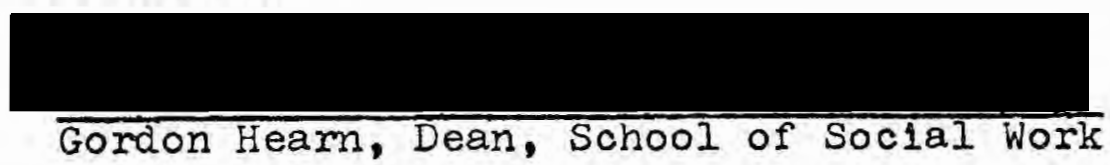

February 28, 1972 


\section{ACKNOWLEDGMENT}

We wish to acknowledge and thank the following persons who contributed so much to this study: Dr. Burritt W. Newton, Department of Obstetrics and Gynecology, Un1versity of Oregon Medical School, who sanctioned our conducting the research at the Medical School; Dr. Quentin D. Clarkson, Associate Professor of Statistics, School of Soclal Work, Portland State University, and June Dunn, Director, Maternal and Child Health Training Project, Portland State University, for giving us so much of their time, counsel, and guidance as well as for their critical readings of the various drafts of the manuscript; Leslie W. Hunter, Director of Social Service, University of Oregon Medical School, and his staff for their co-operation.

Our special thanks and appreciation are extended to the 7.8 anonymous women who were the subjects of our research and whose co-operation made this study possible. 
CHAPTER

I INTRODUCTION

The Law and the Hospltal ......... I 1

The objective .................... 2

The Population ................... 3

Methodology ...................... 5

II A REVIEW OF THE IITERATURE .......... ?

III RESEARCH DATA

Soc1al Data .................... 13

Psychological Data.............. 17

Comparative Data .................. 18

List of Comparisons ............ 2 ?

IV SUMMARY ....................... 29

V ANALYSIS ....................... 32

VI RECOMNENDATIONS ........................ 38

LIST OF REFERENCES $\ldots \ldots \ldots \ldots \ldots \ldots \ldots \ldots \ldots \ldots \ldots \ldots . \ldots . \ldots . \ldots \ldots$

APPENDIX ..................................... 45

QUESTIONNAIRE ........................... 48 


\section{LIST OF TABLES}

TABLE

PAGE

I Demographic Characteristics of Women Seeking

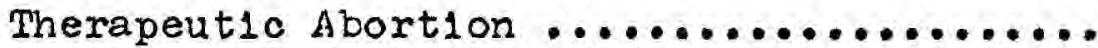

II Legal and Women's Personal Reasons for the

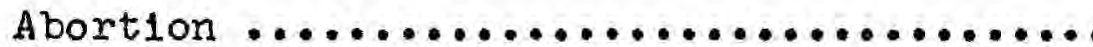

III Woman-Father of the Child Relationship Prior

to Pregnancy and At Time of Abortion ......

IV The Women's Impressions of Attitudes Toward

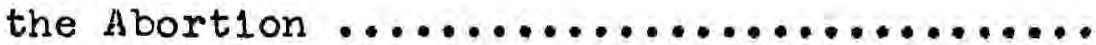

V MMPI -- D Scale Raw Score for Normal Women

and Raw and T Scores for Women Having

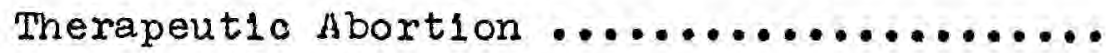

VI Composite of the Average Woman From Th1s

study $\ldots \ldots \ldots \ldots \ldots \ldots \ldots \ldots \ldots \ldots \ldots \ldots$

VII Comparison of Attitude of Friends Toward the

Abortion with $T$ Scores on D Scale of MMPI..

VIII Comparison of Attitude of Father of Chlld

Toward Abortion with $\mathrm{T}$ Scores on D Scale

of MMPI

22

IX Comparison of Women's Marital Status with T

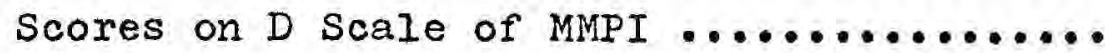

$X$ Comparison of Women's Marital Status with

Mother-Father of the Ch1ld Relationsh1p

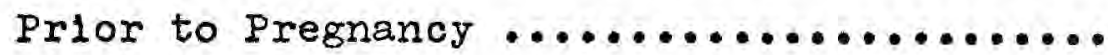


XI Comparison of Women's Feelings About the

Abortion With Their Personal Reasons for

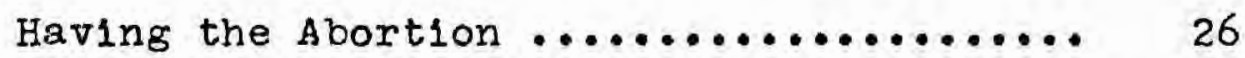

XII Comparison of Women's Marital Status with

Women's Personal Reasons for Having

the Abortion $\ldots \ldots \ldots \ldots \ldots \ldots \ldots \ldots \ldots \ldots \ldots$ 
CHAPTER I

\section{INTRODUCTION}

\section{THE LAW AND THE HOSPITAL}

For several years public pressure had been bullding In the state of Oregon for a more I1beralized abortion law. Opposition to such a liberalization was also widespread, based primarily on moral and rel1glous reasons. In 1969, Oregon Law 435.415 was passed I1beralizing the previous law regarding therapeutic abortions, This law states: Justiflable termination of pregnancy by a physician

(1) A physician is justifled in terminating the pregnancy of an Oregon resident if he has reasonable grounds for belleving that:

a) there is substantial risk that continuance of the pregnancy will greatly impair the physical or mental health of the mother;

b) the child would be born with serious physical or mental defect; or

c) the pregnancy resulted from felonlous intercourse.

(2) In determining whether or not there is substantial risk under paragraph (a) of subsection (1) of this section, account may be taken of the mother's total environment, actual or reasonably foreseeable.

(3) A justifiable termination of a pregnancy shall be performed only by a physician in a hospital.

This Iiberalization affected the state hospitals particularly because of section (3) of ORS 435.475 whlch states that:

No hospital operated by this state or by a political subdivision in this state is authorized to adopt a policy of excluding or denying admission to any person seeking 
termination of a pregnancy under oRS 435.415.

Consequently the Unlversity of Oregon Medical School Hospital in Portland, Oregon, as of August 1, 1969, began to offer the service of abortions according to the law. The Obstetrios and Gynecology Department of the hospltal estabI1shed an abortion service and asked the Social Service Department to add facliltating care to the patients.

\section{THE OBJECTIVE}

Th1s evaluation was undertaken because of an interest by the authors in the abortion program at the Medical school. Interest in the emotional status of patients receiving abortions was aroused whlle working in a fleld placement at the Medical School through the Portland State University School of Soclal Work. (See Appendix A for a summary of the abortion problem in Oregon under the first year of the reformed law.)

W1th the consent and assistance of the Obstetrics-Gynecology Department and the Director of Social Services, this study was initiated with the hope that it would be a step toward providing an over-all and continuing assessment of information about the women recelving abortions. The researchers' partlcular area of interest concerned the characteristics of emotional depression as they relate to the abortion process. A decision was made that this study would concentrate on gathering data in relation to three aspects of the sample:

1. To describe the sample through demographical terms and attitudes; 
2. To describe the amount of depression the women have prior to recelving the abortion;

3. To determine if some clrcumstance or attitudes have a correlation with the amount of depression of the women.

\section{THE POPULATION}

The University of Oregon Medical School Hospital is primarily a teaching hospital and in that capacity it serves the entire state of oregon. Consequently the patients represent a cross section of diseases and medical problems. The women recelving abortions fall largely into three different groupings: (1) The first group is composed of those patients who present an unusual medical problem or risk. Private physiclans often refer these patients feeling that the program and equipment avallable at the Medical School would be important to their patients. These situations also provide a learning experience for the medical students. (2) Patients who are not receiving welfare payments but who can not afford a private physician form the second group. (3) A patient recelving welfare who cannot find a physiclan avallable to complete the abortion within the required time limit make up the third classification.

The women receiving abortions at the Medical School primarlly are of the second category, not recelving welfare, but unable to afford a private physician. Women recelving welfare payments do not, under ordinary clrcumstances, recelve abortions at this hospital because the Welfare Department has medical funds avallable through Title 19 for 
private physicians; therefore, they would be treated in the normal flow of medical services.

During an interview with the Director of Social Services an initial judgment is made as to whether the woman, because of her total environmental and emotional situation, seems to be an appropriate candidate for an abortion. Alternative planning is discussed and, whatever decision is reached, assistance in the necessary adjustments and adaptations are 1mmediately offered.

After the initial interview with the Director of Social Services, if a pregnancy test is needed this is arranged and the date for the abortion is tentatively assigned. There are basically two medical procedures used according to the size of the embryo or fetus. When the pregnancy is thirteen weeks or less, a dilatation and curettage is performed. However, if the gestation period is between sixteen and twenty-two weeks a saline injection into the womb is necessary to induce labor. The women recelving abortions are divided into groups. There is a new group of approximately ten women each week. At the time of this study each group would meet with a doctor, a nurse, and two soclal workers from the Soclal Service Department. Frlends and relatives are welcome to attend the meetings. The purpose of the group meeting is for the four staff members mentioned above to inform the women of the hospital procedures regarding the abortion, contraceptive methods, to alleviate the women's anxiety arising from the pending abortion, etc. 


\section{METHODOLOGY}

A questionnalre (See Appendix B) was devised to obtain the desired information for the study. The questionnalre was distributed to every woman who was accepted into the clinic for a therapeutic abortion beginning in May, 1971, and continuing Into June, 1971, unt1l 78 questlonnalres were completed. Immediately following the interview with the Director of Social Services, in which the woman was advised she would recelve the abortion, the Director requested her co-operation in completing a questionnaire for research purposes. A secretary showed the woman to a room and gave her the questionnaire with a minimum of explanation. The woman was assured that ne1ther her name nor any other means of 1dent1flcation would be placed on the questionnalre. The woman was left alone and was asked to return the questionnalre when 1t was completed. No one refused to f1ll out the questionnalre and all questionnalres were returned. Not all questions, however, were answered on all questionnalres.

In drawing up the questionnalre we anticlpated a wide range in the educational level of the women. The questions were multiple cholce but constructed so that only one answer could be given to each question. There were no open-ended questions.

The demographic questions concerned the woman's age, race, education, marital status, and religion. The questions about the woman's attitude toward the abortion and some of the clrcumstances of her 11fe-situation were asked because it was 
belleved that these would probably influence the degree of her depression about the abortion. She was asked to rate how she saw the relationship between the father of the child and herself as well as to indicate if the father knew of the pregnancy and abortion. In order to discover if the woman was receiving support in her decision to have the abortion she was asked to rate what attitude she felt her family," frlends, and the father of the child had toward the abortion and if they knew about her decision. It was also felt that the woman's living arrangements, particularly her 11 ving proximity to the father of the child and her family, might have some bearing on her depression. She. was asked, therefore, to indicate her living situation according to her marital status. To gain some insight as to why the woman was seeking the abortion she was asked to indicate both her personal reason and the legal reason for the abortion. We conjectured, also, that the longer the woman carrled the child the more depressed or the more relleved she might be to have the abortion. The type of medical procedure used in performIng the abortion was thought to be an influence. For these reasons she was asked to indlcate the present length of her pregnancy.

To estimate the amount of depression the woman was experiencing we used three devices.

1. The D scale of the MMPI: $8,9,10$ This scale from this standard test was administered at the same time as the questionnaire. This standardized test provided us with a means of measuring our sample against the normal population. 
2. The Mood scale: This is a device employed by the Crisis Unit of the Multnomah County Hospital in Portland. It is a shorthand method of determining the amount of depression the woman is experiencing by asking her to rate herself. She is asked to rate herself by the following question: "If 100 is the happlest you have ever felt and 0 is the unhapplest you have ever felt, how would you rate yourself right now?" We felt it desirable to have this subjective test combined with the objectivity of the MNPI depression scale. Although the validity of this test has not been established 1t has been considered as a valuable diagnostic tool by some professionals at the Medical School.

3. In order to round out the measurement of depression, we asked the woman to decide which best described how she felt about having the abortion: happy, unhappy, regretful, guilty, don't care, or relleved. 


\section{CHAPTER II}

\section{A REVIEW OF THE IITERATURE}

In the following review those articles, sections of articles, books and sections of books w1ll be summarlzed that are applicable to the toplc of the present study. The primary concentration w1ll be on (1) population description, (2) the emotional situation especially the amount of depression the women experience prior to the abortion, and (3) clarifying the factors that influence this depression.

Before proceeding to a review of the literature $1 t$ seems important to point out some of the difflculties such a task presents.

First of all, there are no studies that have been done on the exact topic under consideration here. Studies have been done on follow-up of women having had abortions to determine the amount of prychiatric 111ness caused by the abortion. 6,13 , 14, 22, 24, 26, 27 Articles have been written about the advantages and disadvantages of therapeutic abortions from moral, medical, legal, and psychological viewpolnts. 2,4,7,17,19,26 A variety of comparisons have been made: women who had criminal, spontaneous or therapeutic abortion $3,12,27$ and those approved and those refused for therapeutio abortions. 12 A synopsis of the history of abortion was presented in one study. ${ }^{16}$ This variety of articles made it necessary to glean information from Incongruent sources. 
A second difflculty in this review was the lack of consistent information about the women prior to the abortion. simon and senturia ${ }^{25}$ point out after their rather extensive review of the 11terature that few of the earlier studies take into consideration, in a scientific manner, the psychological condition of the women before the abortion.

A third hurdle to negotiate in attempting to draw some conclusions from this review was that it was hazardous to make valid comparisions between the studies. The method of data collection varied wldely: interviews following the abortion to assess attitude before and after abortion, 30 gathering of information from medical records $1,15,25,26,27$ conjectures from clinical experience, 4,11 and interviews before and after the abortion. 3,12 The studies were conducted under elther stringent laws $1,4,5,6,11,15,17,22,23,26,27,28,30$ or I1beral abortion laws 1, 3, 16, 19,23, 24 that affected sharply the type of women who would particlpate in the studies. The stringent laws allowed abortions only if psychosis or sulcide seemed fmirient. In fact Patt and Rappaport 22 attempted to assess how much the women exaggerated the ir chances of being granted the abortions under the tougher laws. This dichotomy between stringent and liberal laws led Judith Rappaport 24 to study women from America (where the law was stringent) seeking abortions in Sweden (where the law was 11beral)。

Hamilton $(1940), 6$ in his first study, found that prior to the abortion $45 \%$ of the women felt regret about the abortion, 
$39 \%$ felt rellef, and $15 \%$ were indifferent. This study wes done in this country under stringent laws and this sample consisted of women having spontaneous orlminal as well as therapeutic abortions.

Hamilton (1941)5 and W1Ison (1952)30 showed that the relationship between the father of the child and the mother tended to deteriorate following the abortion.

Ekblad, $(1955)^{3}$ studying 479 women in his native Sweden under liberalized law found that of those granted abortions on psychiatric grounds $47 \%$ had normal personal1ties, $58 \%$ had abnormal personalities. Malmfors (1958), ${ }^{18}$ also in Sweden, surveyed 84 women before and after abortions and found that ten suffered impairment of their mental health following the abortion. All ten of the women had neurotic complaints before the abortion. This finding was stated by Wilson 30 as one of his conclusions: the response of the woman to the abortion was very much related to her personality make-up. simon et al. 26 also concluded that the psychiatric diagnostic indications for abortion do not appear to be as important a determinant of the way that the abortion w1II be dealt with as the over-a.1 psychological balance of the women involved. Krummer $(1963)^{15}$ reviewed the major 11terature on abortion and the women's reaction to 1t. His conclusion was that abortion is a precipitating stress towards moderate to severe psychiatric 1liness. He also felt. that abortion, however, as a precipitating stress is no more severe than other non-specific factors: disappointment in love, an accident, 
or loss of a job.

Judith Rappaport (1965) 24 did a study of American women seeking abortions in sweden. The women in her study were predorinantly white, urban, highly educated and in the upper economic range. She concluded (I) that the group exhibited depressive symptomalogy rather than extreme anxiety, and (2) that it was not possible to separate situational factors from underlying personality characteristics of the women as influences on their reaction to the abortion. simon, et al. $(1967)^{26}$ concluded from thelr study that women" who come for therapeutic abortions are highly selected in terms of their psychopathology. The tests given showed a high incidence of sadomasochism, depression, and rejection of the feminine biological role.

Harrison (1969) ? In writing about abortions and teenagers, not from a research study but from his clinical observations, concluded that pregnancy is a result of emotional disturbance so abortion is a treatment of the symptom rather than the disease.

Simon, et al. (1969) 27 compared women recelving therapeutic abortions with those having spontaneous abortions. Among the spontaneous abortion group the following was found: $40 \%$ had DEPRESSED feelings when told by their obstetrician that the abortion was inevitable, $28 \%$ had feelings of DISAPPOINTMENT, $19 \%$ had feelings of RELIEF, $6.2 \%$ had mixed feelings of DISAPPOINTMENT and RELIEF. Depression was also more common among those women who had planned pregnancy than 
those with unplanned pregnancy. The authors concluded that there are many similarities in personality make-up between the two groups of women. They feel that pre-existing conflicts appear to be important determinants in who recelves a therapeutic abortion and who has a spontaneous abortion. Boyce and osborn $(1970)^{1}$ reported data about women having abontions in a Canadian hospital from 1962-1968 (in 1967 the abortion law was liberalized). The most common grounds for seeking a therapeutic abortion was depression and a lack of external support of relatives and friends. The authors concluded by emphasizing the need, especially for young women recelving abortions, to have external support in making the decision and through the abortion to avold unhealthy emotional consequences. Norman, Wolfington, and Hunter $(1970)^{21}$ agree with this conclusion. In describing the group treatment approach for women recelving abortions, that is used at the University of Oregon Medical School, their opinion is that the group process substitutes for or enhances the support of the woman who is lacking this support from relatives or friends. The authors see this as the most valuable aspect of their treatment modality.

Information concerning the areas of population, emotional situation of the women, and factors affecting the emotional situation was as follows: the populations studied in the reports can be classified into two groups, each with their own characteristics. Those receiving abortions under stringent abortion laws were more psychologically disturbed, older, 
predominantly married and more likely to have other chlldren. Those receiving abortions under more 11 beral laws tended to be less disturbed, younger, predominantly unmarried, and childless. The proportions of religions did not vary between the two groups to any substantial degree.

Simon and Senturia 25 discovered in their review of follow-up studies that they came to a wide range of conclusions conceming the women's emotional reaction after the abortion. In our review concerning women prior to the abortions, varlous concluslons were reached also: (1) the women's response to the abortion seemed to be related to her over-all personality make-up, $18,26,30$ (2) depression seems to be elther a grounds for the abortion or a common reaction to the abortion, $15,24,27$ (3) abortion does seem to be a negative emotional experience for the women, $1,5,21,30$ (4) the women recelving abortions under more likeral. laws are more capable of coping with the situation because of more stable personalities.

Most authors e1ther found it impossible, unnecessary, or did not even consider situational factors separate from personality factors as influences on the women's reactions to the abortion. Some conclusions were drawn, however: the relationship between the father of the child and the mother tended to deteriorate at the time of the abortion, 5,30 abortion was no more a serious precipitating factor in causing depression than other non-specific factors, 15 (3) there was a need, especially among the younger women, for external support for a more effective coping with the abortion. 1,21 


\title{
CHAPTER III \\ RESEARCH DATA \\ SOCIAL DATA
}

The demographic characteristics of the 78 women at the time of the abortion are shown in Table I.

\section{TABLE I}

Demographic Characteristics of Women Seeking Therapeutic Abortion ( $\not \circ=$ Total Sample)

Average age at time of abortion

$$
\text { 21.? }
$$

Age range

$$
14-42 \text { (S.D. }=4.99 \text { ) }
$$

Relision

Protestant

Cathol10

$39(50 \%)$
$14(18 \%)$

Jew1sh

Other

None

0

$15(19 \%)$

$10(1378)$

Race

\author{
White \\ Negro \\ Oriental \\ American Indian
}

$$
\begin{aligned}
74 & (95 \%) \\
2 & (2.5 \%) \\
0 & \\
2 & (2.5 \%)
\end{aligned}
$$

Education

Average highest grade completed

12.3

Grade range

9-18 (S.D.=1.7?)

Marital status

Single

Married

Dlvorced

Widowed

Separated

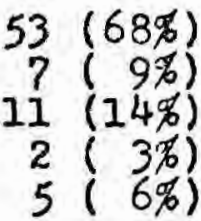

of the 53 single women in the study 32 per cent were Iiving alone, 32 per cent with their parents, 19 per cent 
with another female(s), 14 per cent with the father of the child, and 3 per cent with a man who was not the father.

of the 7 married women 5 were pregnant by the husband and 2 pregnant by another man. None of the women who were IIving with thefr husband became pregnant by another man.

of the 11 divorced, 5 separated, and 2 wldowed women, 2 were pregnant by their husbands with 14 being pregnant by some other man. Two women did not respond to this question. Seventy-five of the 78 women in this study were certain of the identity of the father of the child. Fifty-eight of the fathers knew about the pregnanoy but only 52 had knowledge of the abortion.

Seventy-three women indicated they had been pregnant less than 13 weeks and, therefore, could have the abortion $\checkmark 1 a$ the $D$ and $C$ procedure. Only 5 had been pregnant 13 weeks or longer and, therefore, an abortion induced by $a$ : saline injection would be necessary.

Legal and Personal Reasons for the Abortion: The legal reasons for the abortion were in three categorles while the women's personal reasons were in four categorles (Table II). Woman-Father of the Child Relationship: The 78 women in this study were asked to describe their relationship with the father of the child prior to the pregnancy and at the time of abortion (Table III).

At the time of the abortion 20 women (26\%) were no longer in contact with the father. The data Indicates that the number of women who have an EXCELIENT relationsh1p with 
TABLE II

Legal and Women's Personal Reasons for the Abortion $(\%=$ Total Sample)

Legal Reasons

Mental or physical health of the $50(64 \%)$ woman

Possible mental or physical defect of the child

Rape

No Response

$19(24 \%)$

Personal Reasons

Primarily because the woman herself desired the abortion

Primarily to please the father of the child

Primarily because her doctor advised the abortion

Primarily to please the woman's parents or guardian

No Response

$4(5 \%)$

\section{TABLE III}

Woman-Father of the Child Relationship Prior to Pregnancy and At Time of Abortion ( $\%$ = Sample re. RELATIONSHIP )

\begin{tabular}{lccccc}
\hline & Excellent & Good & Fa1r & Poor & Response \\
\hline Prior to & 37 & 24 & 11 & 4 & 2 \\
Pregnancy & $(47 \%)$ & $(31 \%)$ & $(14 \%)$ & $(5 \%)$ & $(3 \%)$ \\
\hline At Time of & 19 & 20 & 17 & 7 & 1 \\
Abortion & $(24 \%)$ & $(26 \%)$ & $(14 \%)$ & $(9 \%)$ & $(1 \%)$ \\
\hline
\end{tabular}

the father decreases to one-half the number at the time of the abortion. There is also a decrease but not so markedly in the GOOD category. In contrast the number of women in the POOR 
category at the time of the abortion almost doubies.

Attitudes Toward the Abortion: The women's descrip-

tion of the ATTITUDES of the father, their parents, siblings and friends are shown in Table IV.

\section{TABLE IV}

The Women's Impressions of Attitudes Toward the Abortion ( $\%$ = Sample re. ATTITUDES )

\begin{tabular}{|c|c|c|c|c|}
\hline Att1 tude & $\begin{array}{l}\text { Father of Child } \\
\text { (Aware of Abortion) }\end{array}$ & $\begin{array}{l}\text { Women's } \\
\text { Parents }\end{array}$ & $\begin{array}{l}\text { Women's } \\
\text { Stblings }\end{array}$ & $\begin{array}{l}\text { Women's } \\
\text { Friends }\end{array}$ \\
\hline $\begin{array}{l}\text { Unaware of } \\
\text { Abortion }\end{array}$ & $\therefore \quad(26=33 \%)$ & $44(56 \%)$ & $53(68 \%)$ & $49(63 \%)$ \\
\hline $\begin{array}{l}\text { Very Much } \\
\text { In Favor }\end{array}$ & $27(44 \%)$ & $18(23 \%)$ & $12(15 \%)$ & $12(15 \%)$ \\
\hline $\begin{array}{l}\text { Somewhat } \\
\text { in Favor }\end{array}$ & $13(21 \%)$ & $8(10 \%)$ & $4(5 \%)$ & $10(12 \%)$ \\
\hline Indifferent & $12(20 \not z)$ & $I(1 \%)$ & 0 & $1(1 \%)$ \\
\hline $\begin{array}{l}\text { Somewhat } \\
\text { Against }\end{array}$ & $6(10 \%)$ & $2(3 \%)$ & $1(1 \%)$ & $2(3 \%)$ \\
\hline $\begin{array}{l}\text { Very Much } \\
\text { Against }\end{array}$ & $3(5 \%)$ & $2(3 \%)$ & $2(3 \%)$ & $2(3 \%)$ \\
\hline $\begin{array}{l}\text { Parents } \\
\text { Not Living }\end{array}$ & -- & $3(4 \%)$ & $\cdots$ & $\ldots$ \\
\hline No S1blings & $\cdots$ & $\cdots$ & $4(5 \not x)$ & $\cdots$ \\
\hline No Response & $\ldots$ & -- & $2(3 \%)$ & $2(3 \%)$ \\
\hline
\end{tabular}

Total

61 (100;

$78(100 \%)$

$78(100 \%) 78(100 \%)$

There is a consistency in all of the attitude categories. In regards to the women's various relationships, the greatest percentage in all categories were unaware of the abortion with

* Although only 52 of the total sample of 78 indicated the father knew about the abortion, 61 answered the question concerning the attitude of the father toward the abortion. 
those who were very much in favor of the abortion comprisIng a rather distant, second greatest percentage. Those who were somewhat against and very much against the abortion comprised no more than $6 \%$ in each of three of the four relationships. As might be expected the father of the chlid, the fourth relationship with the mother, was against the abortion in almost twice as many cases as the other three relationships combined.

\section{PSYCHOLOGICAL DATA}

MMPI - D Scale: The average raw score on the $D$ scale for the 78 women who completed the MMPI was 24.8 . These scores can be compared with the data obtained by Hathaway

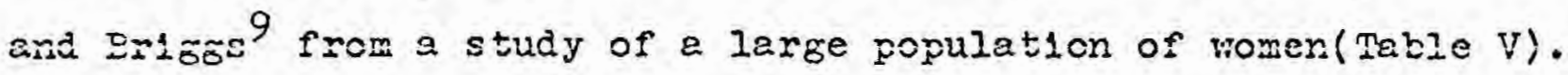

\section{TAELE V}

MMPI $\rightarrow-$ D Scale Raw Score for Normal Women and Rew and $I$ Scores for Women Having Therapeutic Abortion.

D Scale

Average

Raw Score

Range

S.D.

Average

T Score

Range

S.D.
Hathaway and Briggs 9

19.3

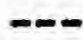

5.18

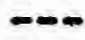

-.-

$\cdots$ Therapeutic Abortion 24.8 11-41 5.52 60.5 24-92 13.10

The abortion group differs statistically significantly from Hathaway and Briggs' 9 population of normal women. 
Twenty-one women (27\%) in the abortion group in our study had it scores above 70 .

Mood Scale: The range of scores on the Mood Scale was $0-100$. The average score was 48.3 with a standard dev1ation of 29.18. There was only 1 score (1\%) of 100, 4 scores (5\%) of 90 , and 6 scores $(8 \%)$ of 85 . In contrast there were 9 scores (12\%) of 0 and 4 scores (5\%) of 10 . In comparing the: two groups of scores $14 \%$ scored $85-100$, a range of 15 . while $17 \%$ scored $0-10$, a range of only 10 . In comparing the extremes of the Mood Scale continuum, therefore, there is a greater number of women who rated themselves toward 0 , the "unhappy" extreme of the scale.

Description of the feelings of the women: When asked to describe their feelings about having an abortion, 34 (43\%) Indicated they were RELIEVED. Only $8(10 \%)$ stated they were HAPPY in contrast with 15 (19\%) being REGRETFUL, 10 (13\%) being UNHAPPY, $7(9 \%)$ being GUILTY, and $2(3 \%)$ expressing an INDIFFERENT feeling. There were 2 women (3\%) who did not express a feeling.

\section{COMPARATIVE DATA}

A chi square statistic was used in testing the independence of cross-classification of 34 comparisons in order to determine significant findings. (See page 27 for the ist of comparisons.) Only 5 comparisons were significant (Probability $=.05:$ (I) the attitude of the friends toward the abortion compared with the T score on the D scale of the MMPI, (2) the attitude of the father toward the abortion with 


\section{TABLE VI}

Composite of the Average Woman From Th1s Study

Age: $21 . ?$

Race: White

Religion: Protestant

Education: High School Graduate

Social class: Iower midale class

Duration of Pregnancy: Less than 13 weeks.

Certainty of Father of Child: Yes

Father has knowledge of pregnancy: Yes

Father has knowledge of abortion: Yes

Marital Status: Single, lives alone or with parents or guardian Relationship with Father prior to pregnancy: Excellent

Relationship with Father at present: Good or no longer in contact.

Attitude of Father toward the abortion: Very much in favor. Attitude of Parents, Siblings and Friends: No knowledge of the abortion.

Legal reasons for having the abortion: Risk to physical or mental health of the mother.

Personal reason for having the abortion: Woman's own desire. Woman's feeling about the abortion: Relieved

T Score on the D scale of the MMPI: 60.5

Mood Scale Score: 48.3

the D scale, (4) the marltal status with the mother-father relationsh1p prior to pregnancy and (5) the woman's personal reasons for having an abortion compared with their feeling about the abortion. Only one of the remaining twenty-nine comparisons came close to being significant.

One of the significant findings concerned the question that asked the women to describe the attitude of their friends toward the abortion (Table IV). This question was compared with the T scores on the D scale of the MMPI (Table VII). For purposes of comparison the responses were divided into three parts: (1) the friends who were in favor of the abortion, (2) those who were not in favor, and (3) those who did 
not know about the abortion.

The range of the $T$ scores in this study was 34-92. The scores for purposes of comparison were divided into two parts: $34-57$ and 59-92. The point of division was determined per Marks and Seeman $(1963)^{20}$. They stated that a raw score of 17 or less ( $T$ score of 46 or less) indicated low depression ("cheerful and optimistic"), 18-23 (T score of 47-57) was normal ("views $11 \mathrm{fe}$ with average mixture of opt1mism and pessimism"), 24-29 (T score of 59-69) indicated mild depression ("mildly depressed or pessimistic"), 30-37 ( $T$ score of 71-84) revealed moderate depression ("moderately depressed, worrying, and pessimistic"), and 38 or more ( $T$ score of 86 or more) indicated marked depression ("severely depressed, worrying, indecisive, and pessimistic"). Because of the disparity between the raw and $T$ score tables, the $T$ scores of 58,70 , and 85 were not included when the above raw scores were converted to $T$ scores. For purposes of brevity the range of $34-57$ will be designated IN (Iow or normal depression) and the range 59-92 MMM (m11d, moderate, or marked depression).

of the 76 women included in this comparison 33 (43\%) were in the $T$ score range of $34-57$ whlle 43 (57\%) were in the range of 59-92.

It is noted that only 3 (4\%) of the 76 women who answered this question were markedly depressed (these 3 women were included w1 th the mildiy or moderately depressed women for comparative purposes). Only I woman whose friends 
Comparison of Attitude of Friends Toward the Abortion with $T$ Scores on D Scale of MMPI ( $\%=$ Sample in each D scale category \}

Attitude

In Favor

Against

Abortion Unknown

No Response
L $N$

$15(65 \%)$

$1(25 \%)$

$1.7(35 \%)$

1
$M M M$

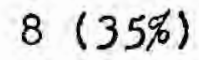

$3(75 \%)$

$32(65 \%)$

1

were in favor of the abortion had a score of 86 or more, none whose friends were against, and 2 whose friends were not aware of the abortion.

The data indicates that where the friends are in favor of the abortion, and thereby provide emotional support to the women, the latter are in a IN state of depression in a rat1o of approximately $2: 1$. In contrast in the instances where the friends are unaware of the abortion and the woman does not recelve emotional support, the women are MMM depressed by the same ratio.

The contrast is even greater when the friends know about but are against the abortion. The women are MMM depressed by a ratio of $3: 1$. It appears, therefore, that when friends are in favor of the abortion, the women react to this emotional support by being in a IN state of low depression. When the friends are against or not aware of the abortion, the women, recelving negative or no emotional support become MMM depressed. The quantity and quality of relationships does 
affect, therefore, the emotional state of the women in regards to the degree of depression.

A second signifloant rinding concerned the question that asked the women to describe the attitude of the father of the child toward the abortion (Table IV). This question was also compared with the $T$ scores of the $D$ scale of the MMPI (Table VIII). For purposes of comparison the responses were divided into two parts: (1) the fathers who were in favor of the abortion including the INDIFFERENT responses and (2) those who were agalnst the abortion.

As previously mentioned only 52 of the women in the study indicated the father of the child was aware of the abortion, but 61 answered the question concerning his attitude toward the abortion. All 61 answers were inoluded in the comparison.

of these 61 women $26(43 \%)$ were in the $T$ score range of 34-57 while $35(57 \%)$ were in the range of 59-92.

\section{TABLE VIII}

Comparison of Attitude of Father of Child Toward Abortion with $T$ Scores on D Scale of MMPI. ( $\%=$ Sample in each D Scale Category )

Attitude

In Favor

Against
L N

$20(38 \%)$

$6(33 \%)$
M M M

$32(62 \%)$

$3(67 \%)$

of the 61 women who answered the question regarding the attitude of the father toward the abortion, only 3 ( $5 \%$ ) had a 
T score of 86 or more. AII of these women indicated that the father was in favor of the abortion. As in the previous. comparison, women who had a $T$ score of 86 or more, markedly depressed, were included with the mildly or moderately depressed women for comparative purposes.

The data reveals that where the father is in favor of the abortion and, therefore, provides emotional support for the woman, the woman is MMM depressed in a ratio of approximately $3: 2$. In contrast where the father was against the abortion and the woman did not recelve the support she was In a LN state of depression in a ratio of $2: 1$.

These findings are in contrast with the first comparison. When the friends were in favor of the abortion the woman was LN depressed, whereas there was MMM depression among the women when the father was in favor of the abortion.

When the friends were against the abortion the women were MMM depressed in contrast w1th the LN state of the women when the fathers were against the abortion.

A third significant finding was obtained when the marital status of the 78 women was compared with the $T$ scores on the D soale of the MMPI (Table IX).

of the total population 44 (50\%) were in the T score range of 59-92 with 34 (44\%) being in the 34-5? range.

In this third comparison there were only 3 women (4\%) of the 78 who scored 86 or more. Two were single and one was divorced. As in the two previous comparisons, the women with $T$ scores of 86 or more, marked depression, were included 
TABLE IX

Comparison of Women's Marital Status with T Scores on D Scale of MMPI. ( $\%$ = Sample in each D Scale Category)

\begin{tabular}{lll}
\hline Marital Status & IN & M M M \\
\hline Single & $26(49 \%)$ & $27(51 \%)$ \\
Married & 0 & $7(100 \%)$ \\
Divorced & $5(45 \%)$ & $6(55 \%)$ \\
Widowed & $2(100 \%)$ & 0 \\
Separated & $I(20 \%)$ & $4(80 \%)$ \\
\hline
\end{tabular}

with the mildiy or moderately depressed women.

A fourth significant finding was revealed when the marital status of the women was compared with the answers to the gucstion that asked the romen to describe the relationship with the father of the chlld before she became pregnant, the four possible answers being EXCEILENT, GOOD, FAIR, and POOR (Table X).

For purposes of comparison the five marital status categorles were combined into three: (1) single, (2) married, and (3) divorced, widowed or separated. The four possible answers were combined into two categories: (1) EXCELIENTGOOD and (2) FAIR-POOR.

of the 76 women who answered this question 61 ( $80 \%$ ) indicated they had an EXCELIENT or GOOD relationship with the father while $15(20 \%)$ had a FAIR or POOR relationship. Four out of 5 women, therefore, had an EXCELLENT or GOOD relationship with the father prior to pregnancy. 
TABLEX

Comparison of Women's Marital Status with Mother-Father of the Child Relationship Prior to Pregnancy. ( $\%=$ Sample in each RELATIONSHIP category)

Marital Status

Excellent-Good

Falr-Poor No Response

\begin{tabular}{lcll} 
Single & $52(85 \%)$ & $8(15 \%)$ & 1 \\
Married & $7(100 \%)$ & 0 & 0 \\
$\begin{array}{l}\text { Divorced, widowed, } \\
\text { or Separated }\end{array}$ & $10(59 \%)$ & $7(41 \%)$ & 1 \\
\hline
\end{tabular}

The group of 10 women in the last category in Table $X$ is composed of 8 divorced women, 1 widowed, and 1 separated. The other 7 women in that category consist of 4 who are separated, 2 divorced, and 1 widowed.

The fifth signifioant finding resulted in the comparison of the answers to the questions that asked the women their personal reason for seeking an abortion with how they felt about having an abortion (Table XI).

For the purpose of comparison the answers to the question regarding the woman's feeling about the abortion were comblned into two categories: (1) HAPPY whlch was a combination of HAPPY, RELIEVED, and INDIFFERENT and (2) UNHAPPY being a combination of UNHAPPY, REGRETFUL, and GUIITY. of the 37 women in the HAPPY category, 28 (76\%) had checked the word RELIEVED on the questionnalre. The word REGRETFUL was checked by 10 (59\%) of the 17 women in the UNHAPPY oategory.

Five $(6 \%)$ of the total sample of 78 did not answer either one or both questions. 
TABLE XI

Comparison of Women's Feelings About the Abortion With Their Personal Reasons for Having the Abortion. $(\%=$ Sample in each FEELING category )

Reason for Abortion

Personal Desire

To Please the Father of the child

On Doctor's Advice

To Please Parents or Guardian
Happy

37 (69\%)

$4(36 \%)$

$2(40 \%)$

0
Unhappy

$17(32 \%)$

$7(64 \%)$

3 (60\%)

$3(100 \%)$

It appears that if the woman is having the abortion because of personal desire rather than being more influenced or coerced by others she is more likely to be in the HAPPY category. Even so, however, one-third of thase women are in the UNHAPPY category.

As previously mentioned only 1 out of the 29 remaining comparisons that proved to be insignificant came close to being significant. The chi square of the comparison of the women's marital status with the responses to the question asking their personal reason for the abortion was 7.624 with a necessary chl square of $7.815(p=.05)$ (Table XII).

For the purpose of comparison the five marital status categories were combined into two: (1) single and (2) married, divorced, widowed or separated.

As shown in Table XII the 37 single women who were seeking the abortion because of personal desire comprise exactly one-half of the total sample in this comparison. 
TAELE XII

Comparison of Women's Marital Status with Womer's Personal Reasons for Having the Abortion. ( $\%$ = Sample in each REASON category)

Maxrled, D1vorced

Reason for Abortion

Single Whadowedoor=8eparated

Personal Desire

$37(74 \%)$

$18(75 \%)$

To Please Father of

the Child

$9(18 \%)$

$2(8 \%)$

On Doctor's Advice

$1(2 \%)$

$4(17 \%)$

To Please Parents or

Guardian

$3(6 \%)$

0

No Response

\section{LIST OF COMPARISONS}

The following is a list of the 34 comparisons for which a chi square statistic was computed.

The T scores on the D scale of the MMPI, the Mood Scale, and the women's feelings about the abortion as compared with:

(1) the attitude of the father toward the abortion

(2) the attitude of the parents toward the abortion

(3) the attitude of the siblings toward the abortion

(4) the attitude of the friends toward the abortion

(5) whether or not the father has knowledge of the

(6) whether or not the father has knowledge of the abortion

(7) the duration of the pregnanoy

(8) religion

(9) the woman's personal reason for seeking an abortion

(10) marital status

Comparisons were also made between marital status and:

(I) the woman's personal reason for seeking an abortion

(2) the present relationship with the father of the child

(3) the relationship with the father prior to pregnancy

The $T$ scores on the $D$ scale of the MMPI were compared 
with the women's feelings about the abortion.

- 
CHAPTER IV

\section{SUMMARY}

A general survey of the population of the present stuay indlcated the following: (1) The age and educational level of the women seeking abortions was very uniform (Table I). (2) Religion was distributed among the women in the same general pattern as among the total population except there were no Jews in the study's population (Table I). (3) The abortion population was overwhelmingly of the Caucasian race, out of proportion with the general population (Table I). (4) The women sought the abortion primari$1 \mathrm{y}$ for their awn well-being rather than because of the insistence of other people (Table II). (5) The relationship of the women and father of the child deteriorated from the inception of the pregnancy to the time of the abortion (Table III). (6) The women felt that her parents, siblings, frlends, and the father of the chlld generally approved of the abortion (Table IV). (7) The women were generally not very depressed and were relleved about the abortion (page 18). (8) The three measures of the women's emotional reaction, the MMPI, D scale, the Mood Scale and the direct question, had virtually no correlation with each other (pages 17-18). The comparisons were done in this study to attempt to discover if any and what circumstances and attitudes might have an effect upon the women's emotional response to the 
abortion. The study revealed the following statistically significant results: (1) The attitude of the women's friends toward the abortion is related directly to her own attitude. In other words if her friends "were in favor of the abortion, then the woman would be less depressed and if the friends were against the abortion the woman tended to be more depressed (Table VII). (2) The attitude of the father of the child toward the abortion tended to have the reverse effect upon the woman's emotional response. If the father was in favor, the woman was depressed and if the father was against, the woman was less depressed (Table VIII). (3) The women who were or had been married previously tended to be more affected, elther negatively or positively, than the single women (Table IX). (4) The married women were more $11 \mathrm{kely}$ to have an excellent or good relationship with the father of the child than were the single women (Table $X$ ). (5) If the woman followed her own convictions in seeking the abortion, rather than those of someone else, she was happler with her decision (Table XI). (6) Three-fourths of the women studled, regardless of marital status, were seeking the abortion for their, own convictions (Table XII).

Some comparisons of the present study with previous studies are as follows: (I) A comparison of the sample of previous studies shows that the women receiving abortion under Iiberal abortion laws were young and single and not very disturbed (page 12). The women of our study, also recelving abortions under a liberal law, followed this pattern (Table I 
and Table V). (2) The general conclusion from previous studies was that depression plays a significant role in the woman's response to the abortion (pages 11-12). This findIng was inconclusive, in the present study. The women were more depressed than the general population but a very small percentage were greatly depressed (Table V). As a matter of fact, more:women in the study were below the "normal" level of depression than were in the "markedly" depressed category. The implication may be that the women who find themselves w1th an unwanted pregnancy and seek an abortion might generally have a more depressed personality make-up than the normal population, but the abortion is not necessarily an Important factor in causing the depression (page 12).

(3) The review of I1terature indicated that the common reactions to the abortion were regret, 6 depression, 1,27 and disappointment. 27 our study, on the other hand, showed the most common response' to be rellef (page 18). (4) The abortion was not an overwhelming cause of depression in the women, no more than other non-specific factors (page 12, and Table V). (5) The present study concurs with previous findings that the relationship between the woman and the father of the child will deterforate between the time of inception of the pregnancy and the abortion (page 12 and Table III). (6) External support, primarily among the woman's frlends, was important as to how the woman responded to the ldea of having an abortion (page 12, Table IV, and Table VII). 
CEAPTER V

\section{ANALYSIS}

The following are the considered opinlons, judgements, and speculations of the authors concerning some of the findings of this study.

The sample: (I) The undform age and education (Table I) are not surprising since this is the age when women are becoming emotionally emancipated . (2) There was a representative distribution of Catholics in the sample population and 1 was interesting to note that they were no more depressed than the rest of the sample (Table I and page 27). Religion played no slgniflcant role with the women. Several reasons come to mind for this situation: (a) In general religion has become less significant in soclety, (b) young people belleve more in a personal moral1ty rather than one imposed from a religious authority, (c) young people emerging from adolescence often find formal religion meaningless, (d) with regard to Catholics there is the present turmo11 in their church causing confusion and thus perhaps weakening Its ability to enforce its moral standards even in its own ranks. (3) The sample incluaed a very small number of Negroes, fewer than the proportion of Negroes in the Portland community (Table I). The unmarrled Negro woman who finds herself with an unplanned and/or unwanted pregnancy discovers that 1 t is more acceptable among her friends and 
family and recelves help to keep and rear the child. Also the Medical School, geographically, is not in close proximity to the Negro community while Emanuel Hospital is located in their community and is one of the largest maternity hospltals in the city. In adaltion in the Negro community there seems to be some susplcion and fear of the Medical School-Multnomah County Hospltal complex. (4) The fact that the women generally made a decision to have the abortion without the Influence of others, adds credence to the study's discovery that the women were not severly disturbed (Table II and Table V). (5) The deterioration of the relationship of the mother and the father (Table III) has several possible explanations. A Joung, immature romant1c relationship is normally unstable. A traumat1c experience, such as an unwanted pregnancy, tends to dismupt a courting relationship. D1sillusionment about the pregnancy not leading to a more permanent relationship and the common defense mechanism of projection -- each blaming the other for the pregnancy -mlght lead to the unsatisfactory relationship. (6) The woman whose fam1ly, friends, and father of the child knew about the abortion generally had their support (Table IV). If she did not have the1r support she probably would not seek the abortion because either she might be agalnst the abortion also or be unable to resist the objections of these people. (7) Over one-half of the women did not tell their families or friends about the abortion and more than one-third did not tell the father of the child about the abortion (Table IV). The 
speculation is that the women were afrald of refection in one form or another; for example, rejection of her conviction to have the abortion, rejection of her personally because of the soc1al stigma of being pregnant out of wedlock and seeking an abortion. The woman may avold telling the father of the child to save him from feeling gullty about her pregnancy. The woman may also feel that the child is only hers, not his, and therefore sees no need to seek his advice regarding an abortion.

There were unexpected results from the three tests used to measure depression (the MMPI, D scale, the Mood Scale and the direct question). The assumption was that if one measuring instrument indicated a woman was depressed, the : other two would show the same; however, this did not happen. All three scales were independent of each other. The speculation is that the three tests measured different aspects of depression. It is belleved that the $D$ scale measured the over-all life position of the women (pessimistic or optimiet1c), the Mood Scale indicated how the whole situation of pregnancy and abortion fit into a lifetime of experiences, and the direct question was an lmmediate stralghtforward response to the abortion. This clearer ldea of what the tests measured explains the discrepancies; for example, a girl could be optimistic (Iow D scale score), frustrated with herself for getting pregnant and having to go through all the complications of getting an abortion (Iow Mood Scale score), and yet be relleved (the direct question) about 
being able to zeceive the abortion.

C1rcumstances and att1tudes related to depression:

(1) The direct relationshlp between the woman's response and her friends' attitude (Table VII) could be explained partially by the fact that at the age and maxital status of these women, young and single, peer relationships are the most important relationsh1p and most decisions are based on this group's morallty rather than on parents: or her own values. (2) The reverse reaction between the father of the child's attitude and the woman's response (Table VIII) might be seen as a reflection of the symbiosis of the mother-child relationship. If the father is in favor of the abortion the woman would be depressed because the rejection of the unborm child is seen as a rejection of her whether or not she is in favor of the abortion. Conversely, if the father is against the abortion the mother would be less depressed when she does have the abortion because she sees him as accepting her and their relationship. Perhaps this is a natural feminine-maternal response. (3) There is an apparent contradiction between (1) and (2) above. In (1) the woman's response to the abortion matches the attitude of her friends, but in (2) the woman's response is contrary to the father of the child's attitude. This discrepancy might be explained by the fact that from her friends the woman is seeking support for her decision to have the abortion but from the father of the child she is asking reconfirmation of their relationship.

On the D scale onemalf of the single women scored in 
the IN range and one-half in the MMM range whereas all the maxried women had an MMM score (Table IX). Th1s points up again the importance of the woman-father of the child rem lationship with regard to the "mother's emotional response to the abortion. The single woman since she is generally not living with the father of the child can more easily disregard or accept his attitude to the abortion and not be so concerned about what may primarily be only a passing sexual relationship. The married woman cannot take her relationship with her husband Iightly; she is with him every day and they mold each others attitudes and decisions. The variation in intensity between the relationships would seem to partially explain the differences in depression.

Comparisons W1th other Studies: The women were more depressed than the normal population, as measured by the MMPI, but the abortion itself was not remarkably disturbing to them (pages 17-18). The fact that the women were generally depressive might support the finding of simon et al. ${ }^{26}$ that the women seeking abortions are pre-selected by their psychological make-up, their general pessimism being only a symptom of deeper disturbances. On the other hand, the average woman in our sample was not very depressed by the abortion 1tself. Some suggested explanations might be the following: (1) She knows that a pregnancy interferes with the IIfe style of a single woman; (2) there are still too many complications for a single girl to rear a child in our soclety: (3) as she sees more liberalized laws passed and 
the changing role of women, she feels that society is more accepting of abortion; (4) she might feel that an abortion might be the only means of saving or on the contrary, removing all vestige of her relationship with the father of the child; (5) if the woman feels guilty about belng pregnant then permission to have the abortion might relleve her gullt. Those women who recelved moral support from family and/or friends in her decision to have the abortion were less depressed than those who were not able to recelved this support (Table XI). Over one-half of the women sald that theix families and friends did not know about the abortion (page 16) so could not lend their support. The woman might have kept her secret either to avold seemingly certain rejection or because of a personality whlch tends to withdraw or avold people in general. In elther case she would carry the responsibility and consequences of the abortion by herself and perhaps, thexefore, increasing her depression. It seems possible that a group treatment process at the time of the abortion may substitute for the lack of support; from friends and family. 


\section{CHAPTER VI}

\section{RECOMMENDATIONS}

In making this study several other areas of need for further investigation in the abortion fleld became apparent: F1rst, an accurate follow-up study of the response of women at various intervals after the abortion. The review of I1terature provided inconclusive follow-up information. 25 The present study indicates the emotional response of the women as recorded at the time they learn they can have an abortion, but this may only be a reaction to this information rather than the total situation. Because the women are generally more depressed gives indications of possible deeper disturbances which may cause adjustment difficulties later.

Second, a study similiar to the present study on the fathers of the children being aborted should be of interest especially since no study has been done on this topic. Since the present study indicates that the father's attitude and the type of relationship in which he is involved affects the woman (Table III), it seems likely that the woman's attitude would affect the response of the father also. L1kewise since the mother-chlld attachment affected the depression in the women, w11 the father-child attachment simliarly affect the father? Thlod, because of the restricted population of our study, a duplication of the present 
study in other hospitals whose patients have a wider range of income would be valuable.

Fourth, this was an exploratory study. What is needed to fill in information gaps is a more detalled study of the background and c1rcumstances of the women recelving abortions In an attempt to clarify the factors that influence their emotional responses. This study might include some of the following ltems whlch were considered for the present study but were beyond 1 ts scope and which in retrospect would have given valuable information: (a) the deeper disturbances at which were hinted in this study possibly could be brought out into the open more by giving the short version of the complete MMPI. (b) A more complete psychlatric history of the patient and her family would help the staff more accurately assess which women would be likely to have a more severe emotional reaction to the abortion. The fact that external support was so important could mean that the more psychiatricaliy deturbed person, who would tend to have less such support, would react harshly to the abortion. (c) This study showed that married women responded negatively to the abortion (Table IX). A new study should investigate the number of pregnancies, miscarriages, and previous abort1ons the women have had. (d) The study uncovered that one-fourth of the women recelving abortions are dolng so for reasons other than their own convictions (Table II). This would seem to suggest that a more detalled inquiry be made as to why the women follow the advioe of people other than 
their physician rather than their own convictions. Part of this inquiry might be to find out the woman's alternative solutions if a legal abortion was not granted. Such facts would also give indirect information as to how serious a matter the abortion was to the woman.

It is also recommended that the group treatment process, as employed at the University of Oregon Med1cal School hosp1tal, be evaluated objectively. Our study showed that the women who can reach out and accept support from others w111 find it easier to cope with the abortion (Table VII). How does the witharawn person respond? The woman who does not respond in the group might receive more help from an individual interview. On the one hand the group may arive latent problems even deeper and give them no chance for expression. On the other hand the group may help the woman to universalize the problem and thus offer some relief. Serlous consideration might be given to having the women take the D scale of the MMPI, or perhaps the entire short version of the MMPI, as a diagnostic tool when they find they can have the abortion in order to better determine who would profit from group or individual treatment. This test would also help to identify the women who should be watched for possible bad effects following the abortion. If the MMPI is undesirable the social worker doing the initial interview should be tuned to these considerations.

If the Mood Scale is to be used as a diagnostic tool by the staff and students at the Medical School, a more care- 
ful analysis of precisely what it measures should be undertaken. A comparative analysis with other instruments measureIng depression seems appropriate. One of the most surprising findings of our study was the different dimensions of depression we measured with the three instruments weremployed (page 34).

Finally we would recommend that, as far as possible, the woman's total personality structure, including her coping mechanlsms and behavioral patterns, be assessed in order to assist her with any present difflculties that might arise and to foresee and thus perhaps alleviate possible future disturbances as a consequence of the abortion. 
LIST OF REFEPENCES

1. Eoyce, R. M. and R. W. Osborn, September, 1970. "Therapeutic Abortion in a Canadian City," The Canadian Medical Association Journal, Vol. 103, pp. $461-465$.

2. Calderone, M. 8. (ed.) 1958. Abortion in the United States. New York: Hoeber - Harper.

3. Ekblad, N. 1955. "Induced Abortion on Psychlatric Grounds, "Hcta Fsychlatrica Scandinavica, Suppl. 99.

4. Gehbard, P. H. et al., 1958. Pregnancy, B1rth and Abortion in the United States. New York: Harper and Row Fublishers, Inc.

5. Hamilton, V. C., 1941. "Medical Status and Psychologic Attitude of Patients Following Abortion," The American Joumal of Obstetrics and Gynecology, Vol. 4I, pp. 235-287.

6. Hamilton, V. C., 1940. "Some Sociological and Psychologic Observation on Abortions," The American Journal of Obstetries and Gynecology, Vol. 39, pp. 919-928.

7. Harrison, Collen P., May, 1961. "Teenage Pregnancy -Is Abortion the Answer?" The Pediatric Clinics of North America, Vol. 16, pp. 363-369.

8. Hathaway, S. R. 1957. An Atlas for the Clinical Use of the MMPI. Minneapolis: University of Minnesota Press.

9. Hathaway, S. R. and P. F. Briggs, 1957. "Some Normative Data on New MMPI Scales," The Journal of Clinical Psychology, Vol. 13, p. 364 .

10. Hathaway, S. R. and J. C. McKinley, 1951. Minnesota Multiphasic Personality Inventory. New York: Psychologlcal Corporation.

11. Hefferman, R. J. and W. A. Iynch, 1953. "What is the Status of Therapeutic Abortion in Modern Gynecology?" The American Journal of Obstetrics and Gynecology, V.1. $66, \mathrm{p} \cdot 335$.

12. Hook, Kersten, 1963. "Refused Abortion: A follow-up Study of 249 women whose applications were refused 
by the National Board of Health in Sweden," Acta. Psychiatrica Scandinavica Supplementum, 168, Vol. 39.

13. Kane, Franc1s J., July-August, 1968. "Therapeut1c Abortion - Quo Vadimus," Psychosomatics, Vol.,9, pp. 202-207.

s

14. Kenyon, F. E., November 1969. "Psychiatric Referrals Since the Abortion Act 1967." Postgraduate Medical Joumal, Vol. 45, pp. 718-721.

15. Kummer, Jerome M., Apr1I 1963. "Post-Abortion Psychiam tric Illness -- A Myth?" The American Journal of. Psychiatry, Vol. 119, No. 10, pp. 980-983.

16. Levine, Howard and Franc1s Pugney. "Law, Preventive Psychiatry, and Therapeutic Abortion," The Journal of Nervous and Mental D1sease, Vol. 151, pp. 51-57.

17. Ledz. T., 1954. H. Rosen (ed.) Therapeutic Abortion. New York: Julian Press.

18. Malmfors, K. 1958. "The Problem of Women Seeking Abort1on," Mory Calderone (ed.): Abortion in the United States, New York: Harper and Row Publishers, pp.133I35.

19. Marder, Leon, March 1970. "Psychiatric Experience with a Liberalized Abortion Law," The American Joumal of Psychiatry, Vol. $126 \mathrm{pp}$. $804-808$.

20. Marks, Ph111p A. and W1111am Seeman, 1963. The Actuarlal Description of Atnormal Personality. Ealtimore: The W1Iliam and Wilkins Company.

21. Norman, Ellen, Homer Wolfington and Leslie Hunter, "Dealing with the Crisis of Therapeutic Abortion;" unpublished paper, August, 1970.

22. Patt, Stephen, Richard Rappaport, and Peter Barglow, April 1969. "Follow-up of Therapeutic Abortion," Archives of General Psychlatry, Vol. 20 , No. 4, pp 408414.

23. Peck, A. and H. Marcus, 1966. "Psychlatric Sequalae of Therapeutic Interruption of Pregnancy," The Joumal of Nervous and Mental Disease, Vol. 143, p 417.

24. Rappaport, Jud1th, July 1965. "American Abortion Appl1cants in Sweden," Archlves of General Psychiatry, Vol. 13, No. I, pp. 35-39.

25. Simon, Nathan and Audrey Senturia, October 1966. "Psychia- 
tric Sequalae of Abortion: Rev1ew of the Literature, 1935-1964," Archives of GeneraI isychiatry, Vol. I5, pp. $378-389$.

26. Simon, Nathan, Audrey Senturia, and David Rothman,

Juiy 1967. "Psychlatric Iliness Following Therapeut1c

Abortion," The American Joumal of Psychiatry, Vol. 124, p. $59 f$.

27. Simon, Nathan, David Rothman, John Goff and Audrey Senturia, July 1969. "Psychological Factors Related to Spontaneous and Therapeutic Abortion," The American Journal of Obstetrics and Gynecology. Vol. 104, pp. 799808.

28. Taussig, F. J., 1936. Abortion: Spontaneous and Induced, St. Louis, Mo., D. V. Mosely Co.

29. Walters, G. S. September 1970. "Psychologic and Emotional Consequences of Electlve Abortion: A Review." Obstetrics and Gynecology, Vol. 36, pp. $482-491$.

30. Wilson, D. C. 1952. "Psychlatric Indications of Abortions," Virginia Medical Monthly, Vol. 79, pp. 448-451. 
APPENDIX .

The following article appeared in The Oresonian

newspaper, Fortland, Oregon, on March 17, 1971: '.

There were 7,196 therapeut1c abortions performed in Oregon in 1970, the flirst full year since the new 11 beralized state abortion law went into effect, 5,689 more than in 1969.

In figures released Tuesday by the state Board of Health, the ratin of abortions in 1970 was 200.8 per 1,000 I1ve births, or one abortion for each five infants born.

The highest percentage of abortions were performed from January to June, with a leveling off achleved in the final six months of 1970 . This was attributed to a signiflcant amount of abortions being performed in washington State in the last part of the year, when legal restrictions for abortions were dropped.

"This undoubtedly took some of the pressure off Oregon hospitals since it was probable that some Washington women came to Oregon for their abortions in the first half of the year," sald a health department spokesman.

Idaho is the only nelghboring state that I1mits therapeutic abortions and the spokesman indicated residents of that state may also be seeking abortions in oregon.

Although Oregon has a residency requirement, certification by the expectant mother or her physician as to her residency is accepted. There are no state funds available for investigation or enforcement of the residency requirement.

On a national basis, the U.S. Department of Health, Education and Welfare is beginning to recelve therapeutic abortion tabulations from several states that complle such information and oregon led the way in two categories.

National abortion rates for the first six months of 1970 varled from 5 to 165 per 1,000 live births, with oregon having the highest ratio 
of those states with adequate reporting. Oregon also had the Ereatest percentage of abortions for unmarried women, with 77 per cent belng either single, divorced or separated.

The percentage of women 19 years and under obtaining therapeutic abortions in oregon last year was 34.7 per cent; $20-24$ age group, 35.6 per cent; and the rest 25 years ard over. One hundred 81rls were under 15; 79 were $14 ; 17$ were 13 and 4 were 12 years old. Nine of these under 19-year level were the result of felonious intercourse.

In 97 per cent of the cases, the basis for a pregnancy's termination in Oregon was 11 sted as "substantial risk that continuance $w 111$ greatly impair mother's mental health."

The primary cause most often named for discontinuing a pregnancy for "physical" or "infant defect" reasons was recent exposure or recently experienced rubella. Heart disease in the mother and apprehension of a "congenital anomaly" in the child were other major physical reasons.

During the first quarter of 1970, abortions were performed in hospitals in 20 counties, although 13 experienced less than 5 in the threemonth period. Multnomah County led the early statist1cs with 81 per cent, Lane County had 9.5 per cent and Jackson County had 3 per cent.

As time passed, therapeut1c abortion 11 beralization laws became more widely accepted and more hospitals and doctors became involved. However, records show most women usually had their abortions performed in a county other than their own. The exceptions to this were in Multnomah and Jackson counties.

Oregon has 87 11censed hospitals and 56 of them performed one or more therapeutic abortions last year. Of the 31 where there were no such terminations, 11 were Catholic hospitals and four had no obstetrics department.

It was shown that 65.4 per cent of all Oregon abortions last year were performed in the first trimester ( 12 weeks gestation and under), the period usually belleved to have such terminations without complications.

Statistics showed the I1beralized abortion laws 
may have had $a^{\text {* }} 31 \mathrm{gn} 1 \mathrm{f}^{\prime}$ cant effect on some areas of the state's vital statistics, particularly those involving the continuation of pregnancies affecting unwanted children.

Thus the 1970 "Immature birth" rate, "fetal death" rate and "infant death" rate all showed decreases over the previous year.

Illegltimate births also went down from 88.7 per 1,000 Iive births in 1969 to 82.1 per 1,000 in 1970. 
DO NOT PUT YOUR NAME ON THIS

QUESTIONNAIRE

This questionnaire is for research purposes ONLY. Neither your name nor any other method of identification will be placed on this questionnaire; therefore, please answer all questions as HONESTLY as possible, giving CAREFUL thought to your choice of answers. 
INSTRUCTIONS: Please read each statement and decide whether it is true as applied to you or false as applied to you. If the statement is true, or mostly true, circle the T. If the statement is false, or not usually true, as applied to you circle the $\mathbf{F}$. Sample:

$T$ (F) New York City is in California

(T) $F$ It is light during the day and dark at night.

1. T F I have a good appetite.

2. T F I am easily awakened by noise.

3. T F I am about as able to work as I ever was.

4. T F I work under a great deal of tension.

5. T F I am very seldom troubled by constipation.

6. T F I am troubled by attacks of nausea and vomiting.

7. $T$ F At times I feel like swearing.

8. $T$ F I find it hard to keep my mind on a task or job.

9. T $\bar{F}$ I seicom worry abulit my heaith.

10. $T$ F At times I feel like smashing things.

11. T $F$ I have had periods of days, weeks, or months when I couldn't take care of thinas because I couldn't "get going."

12. $T$ F My sleep is fitful and disturbed.

13. $T F$ My judgment is better than it ever was.

14. T $F$ I am in just as good physical health as most of my friends.

15. T F I prefer to pass by school friends, or people I know but have not seen for a long time, unless they speak to me first.

16. $\mathrm{T} F$ I am a good mixer.

17. T F Everything is turning out just like the prophets of the Bible said it would.

18. T F I sometimes keep on at a thing until others lose their patience with me.

19. T F I wish I could be as happy as others scem to be. 
20. T F I sometimes tease animals.

21. $T$ F I am certainly.lacking in self-confidence.

22. T F I usually feel that life is worthwhile.

23. T $F$ It takes a lot of argument to convince most people of the truth.

24. $T$ F I go to church almost every week.

25. T $F$ I believe in the second coming of christ.

26. T F I don't seem to care what happens to me.

27. T $F$ I am happy most of the time.

28. T $F$ I seem to be about as capable and smart as most others around me.

29. T $F$ I have never vomited blood or coughed up blood.

30. I F I do not worry about catching diseases.

31. T $F$ Criticism or scoulding hurts me terribly.

32. T $F$ I certainly feel useless at times.

33. $T$ F At times I feel like picking a fist fight with someone.

34. T $F$ Most nights I qo to sleep without thoughts or ideas bothering me.

35. $T$ F During the past few years I have been well most of the time.

36. T $F$ I have never had a fit or convulssion.

37. $T$ F $I$ am neither gaining nor losing weight.

38. T F I cry easily.

39. T $F$ I cannot understand what I read as well as I used to.

40. T $F$ I have never felt better in my life than $I$ do now.

41. T $F$ My memory seems to be all riqht.

42. T $F$ I find it hard to make talk when I meet new people.

43. T $F$ I am afraid of losing my mind.

44. T $F$ I feel weak all over much of the time. 
45. T F sometimes, when embarrassed, I break out in a sweat which annoys me greatly.

46. I $F$ I do not have spells of hay fever or asthma.

47. $T$ F I enjoy many different kinds of play and recreation.

48. T $F$ I like to flirt.

49. $T F$ I have at times stood in the way of people who were trying to do something, not because it amounted to much but because of the principle of the thing.

50. T F I brood a great deal.

51. T F I dream frequently about things that are best kept to myself.

52: $T$ F I believe I am no more nervous than most others.

53. T F Sometimes without any reason or even when things are going wrong I feel excitedly happy, "on top of the world."

54. T $F$ I have difficulty in starting to do things.

55. T $F$ I sweat easily even on cool days.

56. $T$ F when I leave home I do not worry about whether the door is locked and the windows closed.

57. T $F$ I do not blame a person for taking advantage of someone who lays himself open to it.

58. $T$ T At times $I$ am all full of energy.

59. $T$ T Once in a while I laugh at a dirty joke.

60. T $F$ I have periods in which I feel unusually cheerful without any special reason.

61. T F My daily life is full of things that keep me interested. 
NSTRUCTIONS: Please place an " $X$ " in the space providad for an answer to each question unless otherwise instructed.

\section{Age:}

2. Race:

White,

Negro,

Oriental,

Indian,

Other

3. Religion:

Protestant, Catholic, Jewish, Other, None

4. Education: (circle the HIGHEST grade completed)

$\begin{array}{llllllllllllllllll}1 & 2 & 3 & 4 & 5 & 6 & 7 & 8 & 9 & 10 & 11 & 12 & 13 & 14 & 15 & 16 & 17 & 18\end{array}$ or more

5. What is your occupation?

6. How far along is your pregnancy?

7. Are you CERTAIN who the father of the child is? yes no

8. Does the father of the child know about your pregnancy?

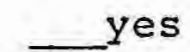
no

9. Does the father of the child know about your abortion? yes no

10. Marital status:

Single,

Married,

Divorced,

Widowed,

Separated

Reason for present abortion:

Great risk to your physical or mental health, OR

A great possibility that the child would be born with a serious mental or physical defect, OR Pregnancy due to rape

12. If married, are you:

Pregnant by your husband, OR

Living with your husband but pregnant by another man, OR Pregnant by some other man

or separated

13. If divorced or widowed,/are you:

Pregnant by your husband, OR

Pregnant by some other man

14. If single, are you:

Living with the father of the child, OR

Living with a man who is not the father of the child, OR Living with your parent(s), OR

Living with another female(s), OR Living alone 
15. Which, in your opinion, BEST describes your relationship with the father of the child BEFO $\overline{\mathrm{RE}}$ you became pregnant? (mark only one) Excellent, _ Good, _ Fair, Poor

Which, in your opinion, BEST describes your relationship with the father of the child Now. (mark only one)

Excellent, Good, Fair, Poor, No longer in contact

16. Which of the following BEST describes how you feel about having the abortion? (mark only one)

Unhappy, _ Don't care, _ Happy, _ Relieved,
Guilty, _ Regretful

17. Which, in your opinion, BEST describes the attitude of the father of the child toward the abortion? (mark only one)

very much in favor

Somewhat in favor

Doesn't care

Somewhat against

Very much against

io. Which, in your upinion, BEST describes the attitude of your parents toward the abortion? (mark only one)

very much in favor

Somewhat in favor

Don't care

Somewhat against

very much against

Parent(s) do not know about the abortion

parents not living

19. Which, in your opinion, BEST describes the attitude of your brother(s) and sister(s) toward the abortion. (mark only one)

Very much in favor

Somewhat in favor

Don't care

Somewhat aqainst

Very much against

Brother(s) and sister(s) do not know about the abortion Have no brothers or sisters

20. Which, in your opinion, BEST describes the attitude of your friends toward the abortion? (mark only one)

Very much in favor

Somewhat in favor

Don't care

Somewhat aqainst

Very much against

Friends do not know about the abortion 
1. Why are you having this abortion? (mark only one) Most of all to please the father of the child. Most of all to please your parents or guardian. Most of all because your doctor advised you to have the abortion. Most of all because you yourself want the abortion.

22. Considering 100 as the happiest you have EVER been and 0 as the unhappiest you have EVER been, how would you rate yourself right NOW? 